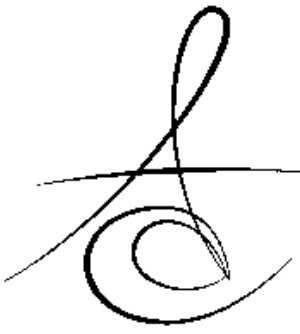

\title{
MICROBIOLOGIC COMPARISON OF SILK, POLYESTER [POLY(ETHYLENETEREPHTHALATE)], POLYGLYCOLIC ACID, AND POLY(GLYCOLIDE-CO-LACTIDE) SUTURE MATERIALS IN ORAL SURGERY ${ }^{\ddagger}$
}

\author{
ORAL CERRAHİ UYGULANAN HASTALARDA İPEK, POLYESTER [POLY \\ (ETHYLENETEREPHTHALATE)], POLYGLYCOLIC ACID VE POLY(GLYCOLIDE-CO- \\ LACTIDE) SÜTÜR MATERYALLERİNİN MİKROBİYOLOJİK AÇIDAN \\ KARŞILAŞTIRILMASI ${ }^{*}$
}

\author{
Dr. Öğr. Üyesi ERTAN YALÇIN* Prof. Dr. HAKAN USLU** \\ Prof. Dr. ERTUNÇ DAYI*
}

Makale Kodu/Article code: 3935

Makale Gönderilme tarihi: 17.12.2018

Kabul Tarihi: 17.05.2019

\section{ABSTRACT}

Aim: The aim of this study is to compare the microbiological colonization on different intraoral suture materials used in patients, undergone oral surgery.

Material and Methods: Suture materials were applied to 60 patients during dentoalveolar surgical interventions. Patients were randomly divided into 4 groups of 15 . Four different types of suture materials were introduced into the patients after surgical removal of their impacted lower third molars. In the postoperative seventh day, suture materials were removed. After these sutures were washed in sterile saline solution containing tubes, we performed various microbiological isolation and differentiation techniques. Results: In microbiological examination, 13 aerobic species, 7 anaerobic species, 1 yeast species, and 1 mold species were isolated from the non-absorbable suture materials. Eight aerobic strains, 9 anaerobic strains, and additionally, 1 yeast and 2 mold strains were isolated from the absorbable suture materials.

Conclusion: In light of the data obtained, we believe that polyglycolic acid based suture materials might be preferred in oral surgery. However, this choice should be made by considering the other features of the suture materials. And also, since the colonization of pathogenic microorganisms could turn the sutures into a potential oral pathogen reservoir, sutures should be removed as soon as possible.

Keywords: Suture materials, microbiological strains, oral surgery
Öz

Amaç: Bu çalışmanın amacı oral cerrahi uygulanmış hastalarda kullanılan farklı sütür materyallerinde meydana gelen mikrobiyolojik kolonizasyonların karşılaştırılmasıdır.

Bireyler ve Yöntem: Sütür materyalleri dentoalveolar cerrahi yapılan toplam 60 hastaya uygulandı. Hastalar randomize olarak herbiri 15 hastadan oluşan 4 gruba bölündü. Gömülü alt yirmi yaş dişi operasyonu yapılan bu hastalara sütür materyalleri intraoral olarak uygulandı. Postoperatif 7. gün sütürler alındı. Alınan sütürler steril salin solüsyonu ihtiva eden tüplerde yıkandıktan sonra mikrobiyolojik izolasyon ve diferensiasyon teknikleri gerçekleştirildi.

Bulgular: Mikrobiyolojik inceleme sonucu olarak; emilemeyen sütürlerde; 13 aerob ve 7 anaerob bakteri türüne ek olarak 1 maya ve 1 küf mantarı türü, emilebilen sütürlerde ise; 8 aerob ve 9 anaerob bakteri türüne ek olarak 1 maya ve 2 küf mantarı türü izole edildi.

Sonuç: Elde edilen verilerin ışığında çalışmamızda kullanılan Sentesorb ${ }^{\circledR}$ sütür materyalinin oral cerrahide tercih edilebileceğini düşünmekteyiz. Ancak bu seçim sütür materyallerinin diğer özellikleri de göz önüne alınarak yapılmalıdır. Sütürlere kolonize olabilen patojen mikroorganizmalar yara yerinde bulunan bu sütürleri potansiyel patojen mikroorganizma rezervuarları haline getirdikleri için sütürler mümkün olan en kısa sürede alınmalıdır.

Anahtar Kelimeler: sütür materyalleri, mikrobiyolojik türler, oral cerrahi

\footnotetext{
* Atatürk Üniversitesi Diş Hekimliği Fakültesi, Ağız-Diş-Çene Cerrahisi AD, Erzurum

${ }^{* *}$ Atatürk Üniversitesi. Tıp Fakültesi, Mikrobiyoloji AD, Erzurum

${ }^{\text {} B u}$ çalışma 4. ACBID Uluslararası Oral ve Maksillofasiyal Cerrahi Kongresi'nde (Antalya/Türkiye)

İngilizce sözlü sunum olarak sunulmuştur.
}

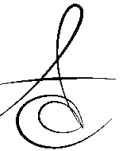




\section{INTRODUCTION}

Sutures are the materials frequently implanted in humans, and are used in all fields of surgery ${ }^{1,2}$. Sutures can be applied in tissue re-approximation operations following to the surgeries or traumas, and also for the purposes of promoting the primary healing or hemorrhage control $3,4,5$ in dentoalveolar surgery as well. A variety of suture materials are currently used in surgery within the mouth, including organic and synthetic, non-absorbable and absorbable materials. ${ }^{2,6}$ One of the benefits of dissolvable stitches is that they usually need no removal. Nonetheless, they stimulate different levels of tissue reactions since they can be degraded by phagocytosis or enzymatic digestion, and hydrolysis. (Greenwald et al, 1994)?

An advantage of non-absorbable suture materials is that they cause minimal tissue response. ${ }^{3,7}$

Suture materials pose potential risks to wound healing process due to their pathogenic bacteria adherence ability. This can be a significant problem in oral surgical operations in which the wound is readily subjected to bacterial contamination in the oral cavity and also to saliva, food residues, ingested liquids, microorganisms, etc. 8,9

The purpose of this clinical study is to analyze the bacterial colonization on suture materials obtained from the patients, undergone intraoral surgery. In our study, we focused on the bacterial species, which we can separate and any differences between the stitches used. Not many studies have implicated the colonization on absorbable and non-absorbable multifilament sutures by oral pathogens, so far. Some researchers have studied the use of multifilament stitches and suggested that it could tent the bacteria into oral tissue, leading to a severe inflammation. ${ }^{10,11}$

Furthermore, biofilms may grow on the sutures post-operatively, causing inflammatory reaction of peripheral tissues or forming a cache, in which pathogens such as bacteria and biofilms are concealed, evading the immune system attacks or becoming less antibiotics sensitive. ${ }^{1,12}$

\section{MATERIALS AND METHODS \\ Suture Materials Used}

1. Silk (Orhan Boz's Med., Ankara, Turkey): Black, natural, nonabsorbable, multifilament suture which is composed of braided Bombyx Mori silk fibers and silicone-coated for noncapillarity.
2. Multicron (Orhan Boz's Med., Ankara, Turkey): Colored in green, nonabsorbable, multifilament suture made up of braided poly (ethyleneterephthalate) filaments (polyester) and coated with silicone to supply noncapillarity and smooth passage.

3. Sentesorb (Orhan Boz's Med., Ankara, Turkey): Violet, synthetic, absorbable, multifilament suture obtained by linear polymerization of polyglycolic acid, coated with the mixture of calcium stearate, polycaprolactone and sucrose fatty acid esters.

4. Laktasorb (Orhan Boz's Med., Ankara, Turkey): Violet, synthetic, absorbable, multifilament suture composed of braided poly (glycolide-co-lactide) copolymer fibers and calcium stearate-coated.

\section{Patients and Study Design}

Informed consents of all patients were obtained. Ataturk University Faculty of Dentistry's ethics committee approved this study by the session 04.2017 and resolution \# 13 . We used different suture materials in sixty patients in several dentoalveolar surgical operations, for example, in a unilateral lower third molar extraction, operated at the Department of Oral and Maxillofacial Surgery, Ataturk University (Erzurum, Turkey). Thirty-six patients were females $(60 \%)$ and 24 were males (40\%), aged 16-75. We divided the patients randomly into 4 groups of 15 . Four different suture materials, specifically silk $\left(\right.$ Silk $\left.^{\circledR}\right)$, polyester (Multicron ${ }^{\circledR}$ ), polyglycolic acid (Sentesorb ${ }^{\circledR}$ ), and polyglycolide-co-lactide $\left(\right.$ Laktasorb $^{\circledR}$ ) were intraorally introduced onto the sutures of the lower third molar. All patients were treated in accordance with the normal standards. We recommended the same oral hygiene practice for all our patients. Patients were chosen among the healthy people with no previous systemic disease, no major hormonal changes e.g. pregnancy, and no drug or substance abuse. In the postoperative seventh day, we removed the sutures in accordance with the standard procedures.

\section{Isolation and Differentiation}

Suture samples in the tubes (Fig 1), containing a sterile saline solution were washed and then put into the tubes with $2 \mathrm{ml}$ Brain-Heart Infusion Broth (BHIB) and $2 \mathrm{ml}$ Scheadler broth (with Vit $\left.\mathrm{K}_{1}\right)\left(\mathrm{Oxoid}^{\mathrm{TM}}\right.$ ). Samples in the BHIB broth were incubated at $35^{\circ} \mathrm{C}$ for three hours and then subcultured onto $5 \%$ sheep 
blood agar (Oxoid $\left.{ }^{\mathrm{TM}}\right)$, incubated at $37{ }^{\circ} \mathrm{C}$ for $24-48$ hours, and chocolate agar $\left(\mathrm{Oxoid}^{\mathrm{TM}}\right)$ incubated at 35 $37{ }^{\circ} \mathrm{C}$ in a $5-10 \% \mathrm{CO}_{2}$ atmosphere for $24-48$ hours. Eosine methylene blue (EMB) Agar (Oxoid ${ }^{\mathrm{TM}}$ ) plates were used for bacteria and incubated at $37^{\circ} \mathrm{C}$ for 24 48 hours. Sabouraud's Dextrose Agar (SDA) (Difco ${ }^{\mathrm{TM}}$ ) and candida chromogenic agar (Oxoid ${ }^{\mathrm{TM}}$ ) were used for yeast, and then incubated at $25^{\circ} \mathrm{C}$ and $37^{\circ} \mathrm{C}$ for 2 weeks. A portion of the samples incubated in Scheadler broth $\left(\mathrm{Oxoid}^{\mathrm{TM}}\right)$ was transferred onto two Scheadler agar plates $\left(\right.$ Merck $\left.^{\top \mathrm{M}}\right)$. One of these plates was incubated at $37^{\circ} \mathrm{C}$ in an anaerobic jar (Oxoid ${ }^{\mathrm{TM}}$ ) (2.5 It) with a Gas-Pak (Anaero-Gen-Oxoid ${ }^{\mathrm{TM}}$ ) for 5 days. Another sample was incubated under aerobic conditions as a control specimen. Rezasurin strips were used for indicating the anaerobic condition in the jar (The Anaerob Indicator-Oxoid ${ }^{\mathrm{TM}}$ ). The yeast growing on SDA was identified with conventional techniques, and bacterial growth in the plates was identified in accordance with the standard conventional techniques. Bacterial colonies were detected by colonial morphology, hemolysis, gram staining, catalase testing, oxidase testing, coagulase testing, by observing the $\mathrm{H}_{2} \mathrm{~S}$ gas release, and Triple Sugar Iron (TSI) agar test. Aerobic bacterial cultures were evaluated by using standard microbiological methods. Streptococci were purified by subculturing on blood agar and identified by using the latex agglutination test with Avipath ${ }^{\circledR}$ Strep (Omega-UK) identification test kit. The yeast and mold cultures have been examined macroscopically for $24 \mathrm{~h}$ and 2 weeks for fungal growth. Fungal isolates were defined based on the colonial macroscopic-microscopic morphology in accordance with the standard methods. Anaerobic bacterial cultures were detected through commercially available API $^{\circledR} \quad 20 \mathrm{~A}$ systems (bioMérieux).

\section{RESULTS}

In the microbiological examination; 13 aerobic strains, 7 anaerobic strains, 1 yeast strain, and 1 mold strain were isolated from the non-absorbable suture samples. Eight aerobic strains, 9 anaerobic strains, 1 yeast strain, and 2 mold strains were isolated from the absorbable suture samples (Table 1).

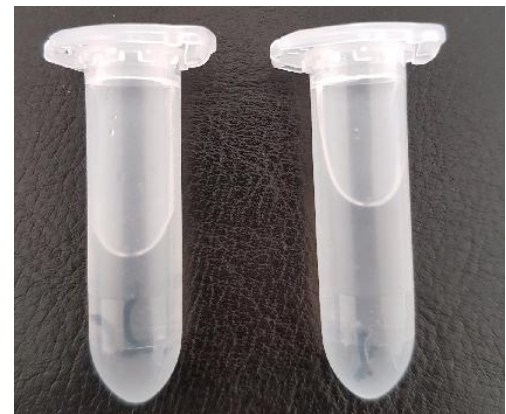

Figure 1. Suture samples in tubes

Table 1. The distribution of bacterial strains obtained from all cultures in the surgical suture materials

\begin{tabular}{|c|c|c|c|c|c|}
\hline & $\begin{array}{l}\text { Silk } \\
\text { n:15 }\end{array}$ & $\begin{array}{l}\text { Sentesorb }^{\circledR} \\
\text { n:15 }\end{array}$ & $\begin{array}{l}\text { Laktosorb }^{\circledR} \\
\text { n:15 }\end{array}$ & $\begin{array}{l}\text { Multicron }{ }^{\circledR} \\
\text { n:15 }\end{array}$ & $\begin{array}{l}\text { Total } \\
\mathrm{n}: 60\end{array}$ \\
\hline \multicolumn{6}{|c|}{ Aerob bacterial strains } \\
\hline \multicolumn{6}{|l|}{ A-Gram positives } \\
\hline Enterococcus spp & 1 & 0 & 0 & 1 & 2 \\
\hline CNS* $^{*}$ & 3 & 3 & 0 & 2 & 8 \\
\hline $\begin{array}{l}\text { Streptococcus } \\
\text { pneumoniae }\end{array}$ & 0 & 4 & 4 & 3 & 11 \\
\hline $\begin{array}{l}\text { Streptococcus } \\
\text { viridans }\end{array}$ & 1 & 4 & 3 & 7 & 15 \\
\hline $\begin{array}{l}\text { Streptococcus } \\
\text { pyogenes }\end{array}$ & 1 & 0 & 1 & 1 & 3 \\
\hline$M S S A$ & 0 & 0 & 1 & 1 & 2 \\
\hline $\begin{array}{l}\text { Corynebacterium } \\
\text { spp }\end{array}$ & 9 & 6 & 6 & 7 & 28 \\
\hline Lactobacillus spp & 4 & 0 & 4 & 3 & 11 \\
\hline Bacillus spp & 0 & 0 & 0 & 2 & 2 \\
\hline \multicolumn{6}{|c|}{ B-Gram negatives } \\
\hline Neisseriae $s p$. & 3 & 4 & 4 & 2 & 13 \\
\hline $\begin{array}{l}\text { Haemophilus } \\
\text { influenzae }\end{array}$ & 2 & 0 & 7 & 5 & 14 \\
\hline E. coli & 2 & 0 & 0 & 3 & 5 \\
\hline $\begin{array}{l}\text { Enterobacter } \\
\text { aeroginosa }\end{array}$ & 0 & 0 & 0 & 1 & 1 \\
\hline \multicolumn{6}{|c|}{ Anaerob bacterial strains } \\
\hline $\begin{array}{l}\text { A-Gram } \\
\text { positives }\end{array}$ & & & & & \\
\hline $\begin{array}{l}\text { Peptostreptococcus } \\
\text { spp }\end{array}$ & 4 & 1 & 4 & 3 & 12 \\
\hline $\begin{array}{l}\text { Eubacterium } \\
\text { aerofaciens }\end{array}$ & 1 & 0 & 1 & 0 & 2 \\
\hline $\begin{array}{l}\text { Lactobacillus } \\
\text { fermantum }\end{array}$ & 0 & 0 & 3 & 0 & 3 \\
\hline $\begin{array}{l}\text { Lactobacillus } \\
\text { acidophylus }\end{array}$ & 0 & 2 & 1 & 0 & 3 \\
\hline Bifidobacterium & 1 & 0 & 0 & 0 & 1 \\
\hline $\begin{array}{l}\text { Eubacterium } \\
\text { lentum }\end{array}$ & 0 & 0 & 1 & 1 & 2 \\
\hline \multicolumn{6}{|c|}{ B-Gram negatives } \\
\hline $\begin{array}{l}\text { Porphyromonas } \\
\text { gingivalis }\end{array}$ & 0 & 1 & 1 & 3 & 5 \\
\hline Veillonella parvula & 0 & 1 & 1 & 2 & 4 \\
\hline $\begin{array}{l}\text { Fusobacterium } \\
\text { nucleatum }\end{array}$ & 2 & 3 & 1 & 3 & 9 \\
\hline Bacteriodes fragilis & 4 & 1 & 1 & 1 & 7 \\
\hline Provetella oralis & 0 & 0 & 0 & 2 & 2 \\
\hline \multicolumn{6}{|c|}{ Yeast } \\
\hline Candida spp & 11 & 0 & 2 & 3 & 16 \\
\hline \multicolumn{3}{|c|}{ Mold } & & & 2 \\
\hline Aspergillus spp & 1 & 1 & 0 & 0 & 2 \\
\hline Penicillium spp & 0 & 0 & 1 & 0 & 1 \\
\hline
\end{tabular}


Nine aerobic strains, 6 anaerobic strains, Candida spp., and Aspergillus spp. were isolated from non-absorbable Silk $^{\circledR}$ samples. Thirteen aerobic strains, 7 anaerobic strains, and Candida spp. were isolated from Multicron ${ }^{\circledR}$ samples. Five aerobic strains, 6 anaerobic strains, and Aspergillus spp. were isolated from Sentesorb ${ }^{\circledR}$-absorbable samples. Eight aerobic strains, 9 anaerobic strains, Candida spp., and Penicillium spp. were isolated from Laktasorb ${ }^{\circledR}$ - an absorbable suture material, samples. Thirteen aerobic strains, 11 anaerobic strains, 1 yeast strain, and 2 mold strains were encountered on all suture samples.

While aerobic strains were isolated from all suture materials, anaerobic strains were not isolated from the samples of 8 Silk $^{\circledR}, 8$ Sentesorb ${ }^{\circledR}, 6$ Laktasorb $^{\circledR}$, and 4 Multicron $^{\circledR}$. Though yeast was isolated from 4 Silk $^{\circledR}, 13$ Laktasorb $^{\circledR}$, and 12 Multicron $^{\circledR}$, it was isolated from none of the Sentesorb ${ }^{\circledR}$ samples. Mold was not isolated from Multicron ${ }^{\circledR}$ samples. However, it was isolated from only one sample per every other remaining suture groups. (Table 1)

We found that Corynebacterium spp, was the most frequently isolated aerobic bacterial strain in the study. It is a normal mouth flora, found in $46.7 \%$ of all samples and encountered mostly on Silk ${ }^{\circledR}$ samples, at a rate of $60 \%$. Corynebacterium spp was isolated from $47 \%$ of Multicron ${ }^{\circledR}$ and $40 \%$ of both Sentesorb ${ }^{\circledR}$ and Laktasorb ${ }^{\circledR}$ samples. The most frequently isolated anaerobic bacterial strain was Peptostreptococcus spp., observed in 12 of 60 samples (20\%) and was encountered most frequently on Silk ${ }^{\circledR}$ and Laktasorb ${ }^{\circledR}$ samples, at rate of $26.7 \%$. Peptostreptococcus spp. was isolated from $20 \%$ of Multicron $^{\circledR}$ and $6.7 \%$ of Sentesorb $^{\circledR}$ samples. Candida spp. was isolated from $26.7 \%$ of all samples (Fig 2,3). However, its distribution on the sutures was surprising. Although Candida spp. was isolated from $73.3 \%$ of Silk $^{\circledR}$ samples, it was isolated from $20 \%$ of Multicron ${ }^{\circledR}$ and from $13.3 \%$ of Laktasorb ${ }^{\circledR}$ samples. Candida spp. was isolated from none of the Sentesorb ${ }^{\circledR}$ samples. In our study, Aspergillus spp. was isolated from one of the 15 Silk $^{\circledR}$ and Sentesorb ${ }^{\circledR}$ samples both. Penicillium spp. was isolated from one of the 15 Laktasorb $^{\circledR}$ samples.

Graphic 1 presents the number of isolated microbial strains on suture samples.

Table 1 presents the distribution of bacterial strains obtained from all cultures in the surgical suture materials used.

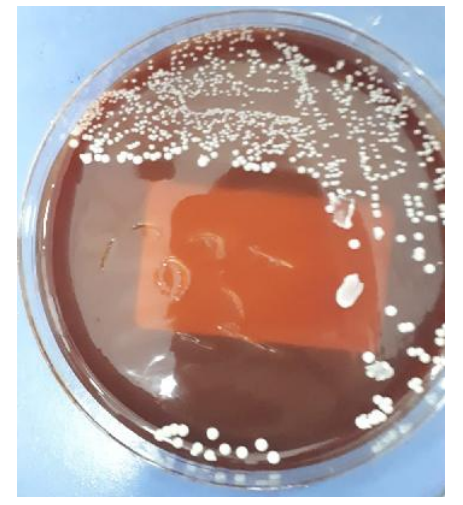

Figure 2. Candida spp. in blood agar

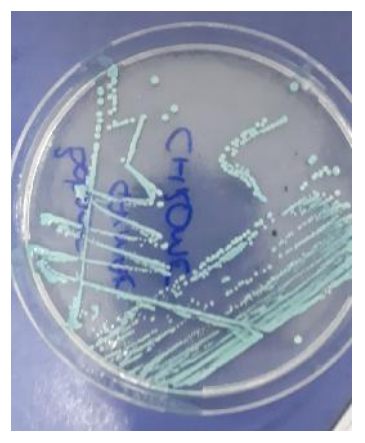

Figure 3. Candida spp. in candida chromogenic agar

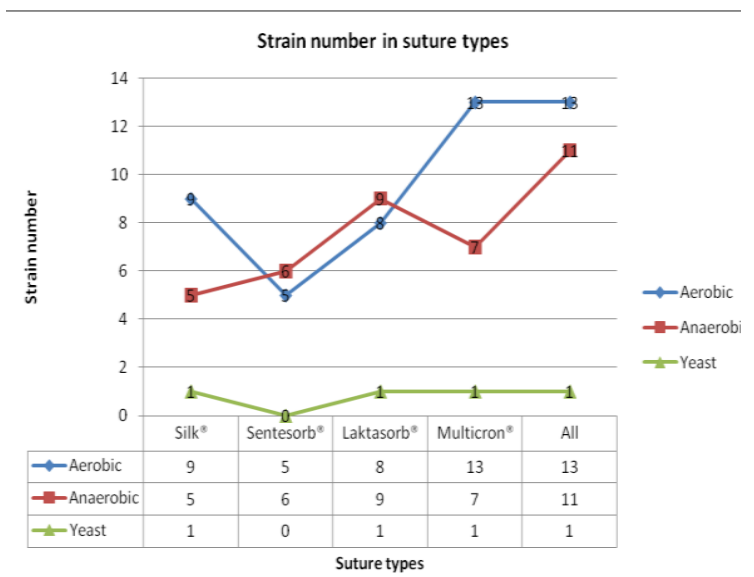

Graphic 1 . The number of isolated microbial strains on suture materials

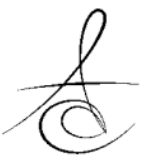




\section{DISCUSSION}

From synthetic polymers to animal by-products, numerous dissolvable and non-dissolvable stitch materials manufactured in monofilament and/or multifilament forms have been applied for incision and/or wound closure in oral surgery. Unlike nondissolvable materials, which trigger only blind inflammatory response ${ }^{3,8,13}$, dissolvable stitches may lead to inflammation, due to a metabolism including phagocytosis and enzymatic digestion. In our study, we tested four different suture materials used in oral surgery: polyester and black silk non-adsorbable sutures, and polyglycolic acid and poly(glycolide-colactide) sutures, which are adsorbed in time.

Many studies have revealed and proved that less inflammatory reaction occurs after the application of monofilament suturing materials in oral wounds than the multifilament types. These researches have been presumed that a "wicking" phenomenon, more frequently seen with multifilament sutures, might cause the spreading of the infection in the wound. ${ }^{8,14}$ Besides, they also report that the bacteria may colonize in the interstices of the multifilament structure ${ }^{15}$ provoking a more protracted inflammatory tissue response $\mathrm{e}^{8,11,16}$ On contrary, Rothenburger et al. ${ }^{17}$ have demonstrated that wound infection was connected with the suture material and its structure, but is not fundamentally based on mono or multifilament composition. ${ }^{8,17}$ We selected all suture materials multifilament in order to keep this from being a determining factor.

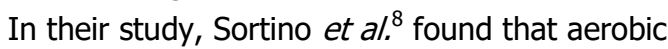
bacterial strains such as Corynebacterium spp., Pseudomonas aeruginosa, Klebsiella pneumoniae, which could not be isolated in our research, were isolated from silk, in addition to the aerobic strains including Neisseria spp., Enterobacter spp., Staphylococci, and certain Streptococcus strains that have also been identified in our study. Nevertheless, we observed that the aerobic bacteria such as Corynebacterium spp., Haemophilus influenzae, Lactobacillus spp., and E. coli, which could not be previously isolated in Sortino et al.'s study were isolated in our study. Although the same study reported that anaerobic strains such as Fusobacterium nucleatum, Peptococcus spp., and Bacteroides melaninogenicus had been isolated from silk sutures, anaerobic bacteria such as Fusobacterium nucleatum, Bacteriodes fragilis, Peptostreptococcus spp., Eubacterium aerofaciens, and Bifidobacterium were isolated in our study. Furthermore, Sortino et al. detected Candida spp. in 9 of a total of 30 samples in their study whereas it was isolated from 11 of 15 samples in our study (Graphic 2). As opposed to our study, Sortino et al. did not isolate any fungi.

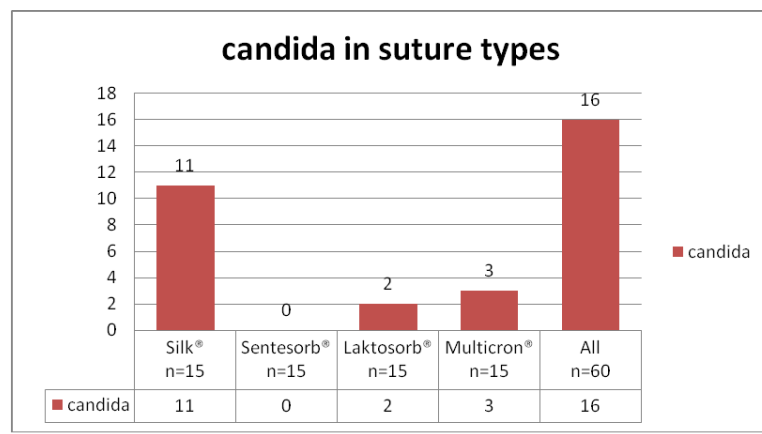

Graphic 2. The differences of distribution of Candida spp. among various suture materials

Aerobic bacteria such as Corynebacterium spp., Coagulase negative staphylococci (CNS), Neisseria spp., Streptococcus pneumoniae, and Streptococcus viridans were isolated from polyglycolic acid based sutures in our study while Sortino et al. had isolated aerobic bacteria such as Streptococcus viridans, CNS, Neisseria spp., and Corynebacterium ${ }^{8}$. In their study, Sortino et al. isolated Bacteriodes melaninogenicus-an anaerobic strain, however we did not. Whereas they identified three types of anaerobic bacteria on polyglycolic acid sutures, we isolated 9 anaerobic strains. Peptococcus anaerobicus and Fusobacterium nucleatus were present in both studies. In their study, Sortino et a/ isolated no Candida spp from polyglycolic acid based sutures, exhibiting the same results with our research.

Banche et al. found that the aerobic strains Streptococcus spp. ( $S$. mitis, $S$. sanguis, $S$. oralis, $S$. mutans, Gemella morbillorum), Staphylococus warneri, Neisseria spp., Actinomyces spp., and Pasteurella spp. and the anaerobic bacterial strains Veillonella parvula, Peptostreptococcus spp., and Fusobacterium spp. were predominant on polyamide, polyester, and

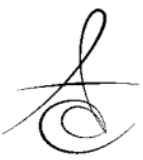


poliglecaprone 25 based sutures ${ }^{10}$. Unlike our study, they observed that the anaerobic bacterial strains of Actinomyces spp., Pseudomonas aeruginosa, and Pasteurella spp. as well as actinobacillus strains, were isolated from sutures. As we isolated Candida spp. from 3 of the 15 polyester suture samples in our study, Banche et al also isolated Candida spp. from polyester sutures in their study.

Among the isolated microorganisms; aerobic $E$. coli, which is a nosocomial pathogen from the Enterobacteriaceae family and normally found in intestinal flora, aerobic Enterobacter aerogenes and Bacteriodes fragilis, which is an anaerobic gramnegative bacterium and also a member of the colon flora, all normally not found in oral cavity and can be isolated from odontogenic abscesses.

In these cases, existence of Bacteriodes fragilis was interpreted as a possible indicator of a nail-biting habit or the use of water and food contaminated by fecal matter. In our study, we found interesting that $E$. coli was not isolated from any of the absorbable suture materials. Although Bacteriodes fragilis was isolated from all suture types, it was observed to be higher amount in Silk ${ }^{\circledR}$ than in the other materials.

In this study, probiotics such as Lactobacillus acidophylus, Lactobacillus fermentum, and Bifidobacterium were encountered. Lactobacillus fermentum was isolated only from 3 of 15 Laktasorb $^{\circledR}$ sutures among all suture samples while Lactobacillus acidophylus was isolated only from absorbable suture samples, though the amounts were minimal. Bifidobacterium, on the other hand, was only isolated from a Silk ${ }^{\circledR}$ sample.

Fusobacteria, Peptostreptococci, Prevotella, and Streptococci species pose a high risk factor for wound healing process and commonly identified in odontogenic infections ${ }^{10,12}$. Due to their suturebonding capacity, these bacteria may be a focal point for odontogenic infection. ${ }^{10}$ Fusobacterium nucleatum was encountered on all types of suture samples on a limited scale. Yet, it could be isolated from only one of the Laktasorb ${ }^{\circledR}$ samples. Peptostreptococcus spp. was present in all suture types however, it was strikingly isolated in a much lower amount from Sentesorb ${ }^{\circledR}$. Provetella oralis could be isolated only from 2 of 15 Multicron ${ }^{\circledR}$ samples. Interesting results were found for streptococcus strains; it is worthy of note that Streptococcus pneumoniae was absent in $\mathrm{Silk}^{\circledR}$, although it was detected in a considerable amount in the rest of the suture samples. Streptococcus viridans streptococci were found in only one of 15 Silk $^{\circledR}$ samples, whereas it was present in a high amount in other suture types, particularly in Multicron ${ }^{\circledR}$. On the other hand, the results for other Streptococcus strains (Enterococcus spp., Streptococcus pyogenes) were not considered as noteworthy since they were isolated in small amounts, although their distribution was different from those of other suture types.

We removed the sutures in the most possible atraumatic way and noted any hemorrhage from the puncture sites, even if they were minor. Brown et al. ${ }^{18}$ reported that the hemorrhage in stitch removing occurred in 47 of 55 patients. Although bleeding was observed in one or multiple sites in $85.5 \%$ of the patients (47 of 55) after the suture removing process and observed in all patients (100\%, 6 out of 6$)$ with positive blood cultures in the post-stitch removal period, their data analysis failed to show a statistically significant correlation between the post-operational hemorrhage and bacteremia incidence. Authors researched the correlation between the stitch removal and bacteremia development concluded that the incidence of bacteremia assured bacterial endocarditis prophylaxis, at least in the patients with high-risk. ${ }^{19,20}$ In our study, antibiotic prophylaxis was not applied, since we only included patients with no systemic disease in our study.

Although the isolated microorganisms were mostly normal mouth and upper respiratory tract flora microorganisms, we found quite interesting that contamination varied with types of suture and based on the microorganism strains. According to the results obtained in our study, Sentesorb ${ }^{\circledR}$ sutures could be classified in the safe suture group in terms of microbiological contamination, since no Candida spp. proliferated, fewer aerobic strains were detected, and a lower amount of anaerobic bacteria was isolated in this type of suture than the other sutures examined. To be more certain on this point, there is a need for a greater number of samples in which oral hygiene is better monitored, as well as need for further studies also monitoring the amounts of cfu (colony-forming units). And different types of sutures removed from the same patient will also enhance the reliability of the study. Otten et al., ${ }^{12}$ although recommend that all their patients should perform the same oral hygiene 
practice, aerobic bacterial strains were observed to be primarily isolated in some patients and anaerobic strains were more prevalent in the others. They explained this by the differences in the time period between oral hygiene practices and the time when the sutures were placed or removed. In our study, this also might be one of the reasons for the different isolations of anaerobic bacteria from the same type of suture samples and for the absence of any anaerobic bacteria in some samples, though they were of the same type. Elderly patients with poor oral health, cardiovascular disorders and patients with immune deficiencies constitute the risk groups for bacterial endocarditis and other systemic diseases of oral origin. ${ }^{10,12}$ In their study, pathogen colonization on the sutures led Otten et al., ${ }^{12}$ to the recommendation that sutures should be removed as early as possible post surgically. In this recommendation, whether the stitch is dissolvable or not is not coherent. ${ }^{10,12,21}$

In conclusion, in light of the data obtained, we believe that polyglycolic acid based suture materials might be preferred in oral surgery, as fewer strains and a lower number of microorganisms were isolated from these sutures; furthermore, some pathogens, including Candida spp., could not be isolated or were isolated only in a small amount. However, this choice should be made by taking other features of this suture material into consideration. Colonization of pathogens in sutures makes them potential oral pathogen reservoirs and requires them to be removed as soon as possible. This recommendation is independent of whether or not the suture is absorbable.

Ertan Yalçın: ORCID ID: 0000- 0003-2785-7576

Hakan Uslu: ORCID ID: 0000-0003-1478-7441

Ertunç Dayı: ORCID ID: 0000-0001-7201-2025

\section{REFERENCES}

1. Yu GV, Cavaliere R. Suture material, properties and uses. J Am Podiatry Assoc 1983; 73: 57-64.

2. Parirokh M, Asgary S, Eghbal MJ, Stowe S, Kakoei S. A scanning electron microscope study of plaque accumulation on silk and PVDF suture materials in oral mucosa. Int Endod J 2004; 37: 776-81.

3. Yaltirik M, Dedeoglu K, Bilgic B, Koray M, Ersev H, Issever $\mathrm{H}$, Dulger $\mathrm{O}$, Soley $\mathrm{S}$. Comparison of four different suture materials in soft tissues of rats. Oral Dis 2003; 9: 284-6.
4. Shaw RJ, Negus TW, Mellor TK. A prospective clinical evaluation of longevity of resorbable sutures in oral mucosa. $\mathrm{Br}$ J Oral Maxillofac Surg 1996; 34: 252-4.

5. Bayer S, Demirtas N, Kazancioglu HO. Suture materials in maxillofacial surgery: A literature review. J Dent Fac Atatürk Uni. 2015; Suppl 11; 105-113.

6. Selvig KA, Biagiotti GR, Leknes KN, Wikesjo UME (1998) Oral tissue reactions to suture materials. Int J Periodontics Restorative Dent 1998; 18: 47587.

7. Greenwald D, Shumway S, Albear P, Gottlieb L. Mechanical comparison of 10 suture materials before and after in vivo incubation. J Surg Res 1994; 56: 372-7.

8. Sortino F, Lombardo C, Sciacca A. Silk and polyglycolic acid in oral surgery: A comparative study. Oral Surg Oral Med Oral Pathol Oral Radiol Endod 2008; 105: e15-8.

9. Chu CC, Williams DF. Effects of physical configuration and chemical structure of suture materials on bacterial adhesion. Am J Surg 1984; 147: 197-204.

10. Banche G, Roana J, Mandras N, Amasio M, Angeretti $A$, Tullio $V$, Cuffini AM. Microbial adherence on various intraoral suture materials in patients undergoing dental surgery. J Oral Maxillofac Surg 2007; 65: 1503-7.

11. Grigg TR, Liewer FR, Patton WR,Buxton TB, Mcpherson JC. Effect of the wicking behaviour of multifilament sutures. J Endod 2004; 30: 649-652.

12. Otten JE, Wiedmann-Al-Ahmad M, Jahnke $\mathrm{H}$, et al. Bacterial colonization on different suture materialsA potential risk for intraoral dentoalveolar surgery. J Biomed Mater Res B Appl Biomater 2005; 74: 627.

13. Giray CB. Clinical and electron microscope comparison of silk sutures and $n$ butyl-2cyanoacrylate in human mucosa. Aust Dent J 1997; 42: 255-8.

14. Lilly GE. Reaction of oral tissues to suture materials. Oral Surg Oral Med Oral Pathol 1968; 26: 128-33.

15. Lilly GE, Armstrong JH, Salem JE, Cutcher JL. Reaction of oral tissues to suture materials.II. Oral Surg Oral Med Oral Pathol 1968; 26: 592-9. 
16. Durdley $P$, Bucknall TE. Assesment of sutures for use in colonic surgery: an experimental study. J R Soc Med 1984; 77: 472-7.

17. Rothenburger S, Spangler D, Bhende S, Burkley D. In vitro antimicrobial evaluation of coated Vicryl plus antibacterial suture (coated polyglactin 910 with triclosan) using zone inhibition assays. Surg Infect 2002; 3: 79-87.

18. Brown AR, Papasian CJ, Shultz P, Theisen FC, Shultz RE. Bacteremia and intraoral suture removal: Can an antimicrobial rinse help? J Am Dent Assoc 1998; 129: 1455-61.

19. King RC, Crawford BA, Small EW. Bacteremia following intraoral suture removal. Oral Surg Oral Med Oral Pathol 1988; 65: 23-8.

20. Giglio JA, Rowland RW, Dalton HP, Laskin DM. Suture removal-induced bacteremia: a possible endocarditis risk. J Am Dent Assoc 1992; 123: 6570.

21. Martin M. Is there a link between tooth brushing and infective endocarditis? Int Dent J 2003; 53: 187-9

\section{Yazışma Adresi}

Dr. Öğr. Üyesi Ertan YALÇIN

Ağız-Diş-Çene Cerrahisi A.D., Diş Hekimliği

Fakültesi, Atatürk Üniversitesi.

25240, Erzurum, Türkiye

Telefon: +90 44223609 40-3562

Faks: +90 4422360945

E-posta: ertanyalcin@gmail.com 